\title{
Viral infection of bacteria and phytoplankton in the Arctic Ocean as viewed through the lens of fingerprint analysis
}

\author{
Jérôme P. Payet ${ }^{1,5}$, Curtis A. Suttle , 2,3,4,* $^{1}$ \\ ${ }^{1}$ Department of Earth, Ocean and Atmospheric Sciences, ${ }^{2}$ Department of Microbiology and Immunology, ${ }^{3}$ Department of Botany, \\ and ${ }^{4}$ Canadian Institute for Advanced Research, University of British Columbia, Vancouver, British Columbia V6T 1Z4, Canada \\ ${ }^{5}$ Present address: Department of Microbiology, Oregon State University, Corvallis, Oregon 97331, USA
}

\begin{abstract}
Viruses are the most abundant biological entities in the oceans and play crucial roles as mortality agents and as catalysts in biogeochemical cycles. During a year-long study in the southeastern Beaufort Sea and Amundsen Gulf in the Canadian Arctic, we used denaturing gradient gel electrophoresis (DGGE) to investigate temporal and spatial changes in gene sequences encoding DNA polymerase B ( polB) and the major capsid protein $(g 23)$ that are specific for the virus families Phycodnaviridae and Myoviridae, which infect phytoplankton and bacteria, respectively. Multivariate analysis indicated that the genetic composition of viruses infecting phytoplankton was related to changes in productivity and hydrological conditions, as well as with changes in the potential host community, as indicated by DGGE fingerprints of 18S rDNA. In contrast, changes in the composition of viruses infecting bacteria could not be related to changes in environmental variables or DGGE fingerprints of bacterial (16S) or eukaryotic (18S) rDNA. Overall, these results document persistent and highly dynamic T4-like viruses and phycodnaviruses on the Canadian Arctic Shelf, implying that they are important in shaping microbial communities in the Arctic Ocean.
\end{abstract}

KEY WORDS: Virus diversity $\cdot$ T4-like viruses $\cdot$ Phycodnaviruses $\cdot$ DNA polymerase B $\cdot$ g23 major capsid protein $\cdot$ DGGE fingerprint $\cdot$ Arctic Ocean $\cdot$ Marine viruses

\section{INTRODUCTION}

Viruses are major players in aquatic systems, with functions as varied as controlling the structure of microbial communities and driving nutrient and energy cycling (e.g. reviewed in Fuhrman 1999, Wommack \& Colwell 2000, Suttle 2005, 2007, Breitbart 2012). Viruses influence aquatic ecosystems by infecting bacteria and photosynthetic and heterotrophic protists; however, the relationships among changes in viral assemblages and variations in the physical and chemical environment are largely unexplored.
Documenting changes in the composition of viral assemblages is facilitated by the use of markers representative of viral taxa. It is particularly informative to be able to track viruses that are representative of those infecting bacteria and eukaryotic microbial assemblages. Good markers are available for T4-like viruses, a group of viruses belonging to the Myoviridae, a family of double-stranded DNA (dsDNA) viruses with icosahedral symmetry and contractile tails (Ackermann 2007). T4-like viruses have been commonly isolated and detected in aquatic environments (e.g. reviewed in Weinbauer 2004, Ackermann 2007). T4-like viruses infect a broad range of phylo- 
genetically distant heterotrophic and autotrophic bacteria, including cyanobacteria (e.g. reviewed in Ackermann 2007, Krisch \& Comeau 2008, Clokie et al. 2010). They exhibit enormous phylogenetic diversity, as revealed through variation in the $g 20$ gene that encodes the portal vertex protein (Fuller et al. 1998, Zhong et al. 2002, Short \& Suttle 2005, Sullivan et al. 2008), the $p s b A$ and $p s b D$ genes that encode core photosynthetic proteins (Mann et al. 2003, Lindell et al. 2004, Millard et al. 2004, Chénard \& Suttle 2008), and the $g 23$ gene that encodes the major capsid protein (MCP) (Filée et al. 2005, Comeau \& Krisch 2008, Fujii et al. 2008, Marston \& Amrich 2009). Additionally, analysis of metagenomic data has corroborated the diversity of T4-like virus sequences in numerous aquatic ecosystems (Breitbart et al. 2002, 2004, Angly et al. 2006, DeLong et al. 2006, Bench et al. 2007, Williamson et al. 2008).

Among viruses infecting eukaryotic phytoplankton, those belonging to the family Phycodnaviridae are best characterized (e.g. reviewed in Dunigan et al. 2006, Wilson et al. 2009, Short 2012). These viruses have large dsDNA genomes, icosahedral symmetry and are widely distributed in many geographically distant environments (e.g. reviewed in Van Etten et al. 2010, Short 2012). They infect many algal species (Wilson et al. 2009, Nagasaki \& Bratbak 2010) and have been implicated in the termination of phytoplankton blooms (Bratbak et al. 1993, Nagasaki et al. 1994, Brussaard et al. 2004). Polymerase chain reaction (PCR) assays targeting conserved motifs of phycodnavirus DNA-polymerase B (polB) (Chen \& Suttle 1995a,b, Short \& Suttle 2002, 2003, Clasen \& Suttle 2009, Culley et al. 2009, Gimenes et al. 2012) or genes encoding the MCP (Schroeder et al. 2003, Larsen et al. 2008, López-Bueno et al. 2009, Rowe et al. 2011) have revealed high levels of phylogenetic diversity of phycodnaviruses in aquatic environments.

PCR-based approaches have been widely used to genetically fingerprint microbial and viral populations. In particular, denaturing gradient gel electrophoresis (DGGE) generates genetic profiles (fingerprints) by separating PCR amplicons based on sequence (Muyzer et al. 1993) and has proved to be a versatile approach for monitoring the dynamics of virus subsets in a wide range of viral assemblages (e.g. reviewed in Short \& Suttle 1999, Sandaa et al. 2010, Short et al. 2010).

For instance, DGGE of g20 gene amplicons has been used to separate T4-like virus portal vertex protein sequences to monitor spatio-temporal patterns in the genetic structure of T4-like cyanophages in various aquatic environments (Wilson et al. 1999, Zhong et al. 2002, Frederickson et al. 2003, Dorigo et al. 2004, Mühling et al. 2005, Sandaa \& Larsen 2006, Wilhelm et al. 2006). Likewise, studies have used DGGE to profile polB amplicons of phycodnaviruses and examine spatio-temporal patterns in the genetic structure of phycodnaviruses in freshwater (Clasen \& Suttle 2009) and coastal marine systems (Short \& Suttle 2002, 2003). Increasingly, DGGE fingerprints in combination with statistical tools have been used to examine the genetic structure of viral subsets and identify ecological factors that influence the dynamics of this structure. However, relatively little is known about spatial and temporal variability in the genetic structure of viral subsets in natural assemblages.

In this study we used DGGE of $g 23$ and polB to examine seasonal and spatial patterns in the composition of T4-like viruses and phycodnaviruses, respectively, in samples from the Canadian Arctic Shelf (CAS), an area subject to high variability in ice cover, irradiance, temperature and runoff from the Mackenzie River (Carmack \& Macdonald 2002, Carmack et al. 2004, Macdonald \& Yu 2006). Multivariate statistical analyses were used to investigate the relationships between changes in the genetic composition of myovirus and phycodnavirus genotypes and environmental conditions and the microbial community structure, with the objective of understanding the environmental factors shaping the genetic structure of viral assemblages.

\section{MATERIALS AND METHODS}

\section{Sample collection and physicochemical measurements}

Between 60 and 2001 of seawater were collected from the CCGS 'Amundsen' from 4 November 2003 to 10 August 2004 on the CAS, during the Canadian Arctic Shelf Exchange Study (CASES), as outlined in Payet \& Suttle (2008). Briefly, seasonal samples were collected at the overwintering station (Stn $200,70.0^{\circ} \mathrm{N}$, $126.3^{\circ} \mathrm{W}$, bottom depth $\sim 230 \mathrm{~m}$ ) during fall (4 and 19 November 2003), winter (weekly from 10 January to 14 February 2004), spring (15 and 21 May 2004) and summer (16 July and 6 August 2004). From December 2003 to June 2004, the ship was locked in ice, so water was sampled through a 'moon pool' in the bottom of the ship. Spatial samples were taken at 7 stations (Stns 906, 803, 718, 650, 415, 200 and 106) along a west-east track starting from the Mackenzie River plume (RP) across the Mackenzie Shelf (mid-shelf, $\mathrm{MS}$ ) to the Amundsen Gulf (G) during summer 


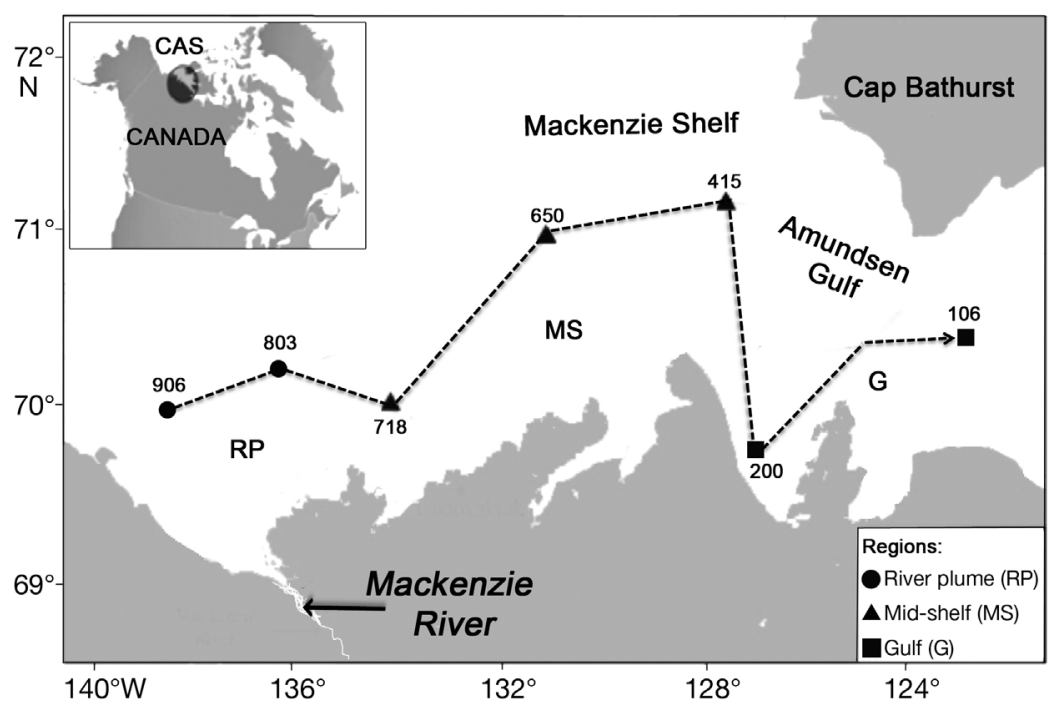

Fig. 1. The study area on the Canadian Arctic Shelf (CAS) showing locations of sampling stations on the Mackenzie Shelf and Amundsen Gulf. Station 200 was sampled from 4 November 2003 to 10 August 2004. Stations 906, 803, 718, 650, 415, 200 and 106 were sampled from 4 July to 10 August 2004 along the cruise track (dashed arrow) from the Mackenzie River plume to the Amundsen Gulf. Stations were grouped into 3 regions: circles, river plume (RP); triangles, mid-shelf (MS); and squares, gulf $(\mathrm{G})$

(4 July to 10 August 2004) (Fig. 1). Water samples were obtained using $12 \times 121$ Niskin bottles mounted on a CTD (Sea-Bird Electronics, SBE-911+) carousel. Depending on the CTD downcast profile, during the spring and summer, water was collected at 2 to 3 depths corresponding to the surface $(<10 \mathrm{~m})$, chlorophyll maximum (if present) or temperature inversion layer $(10$ to $30 \mathrm{~m})$, and below the pycnocline (30 to $60 \mathrm{~m})$. Water samples were filtered through a $120 \mu \mathrm{m}$ mesh and collected in a clean 2001 polyethylene tank.

Hydrological and biological data, including temperature $(\mathrm{T})$, salinity $(\mathrm{S})$, depth, chlorophyll a ( $\mathrm{chl}$ a) concentrations, bacterial abundance (BA), bacterial production (BP) and viral abundance (VA) are from Payet \& Suttle (2008) and Garneau et al. $(2008,2009)$.

\section{Concentration of microbial and virus assemblages}

As previously described (Suttle et al. 1991, Short \& Suttle 2003), the water from the 2001 tank was filtered through $142 \mathrm{~mm}$ diameter glass fiber (GC50, $1.2 \mu \mathrm{m}$ pore size, Adventec MFS) and polyvinylidene fluoride (PVDF, $0.45 \mu \mathrm{m}$ pore size, Millipore) filters connected in series. Particulate matter in the $0.45 \mu \mathrm{m}$ filtrate was then concentrated to $\sim 0.51$ using a $30 \mathrm{kDa}$ cutoff spiral-wound ultrafiltration cartridge (S10Y30, Millipore) mounted on a ProFlux M12 tangential flow filtration system (Millipore). Subsamples from the concentrated viruses (VCs) were placed into triplicate $2 \mathrm{ml}$ sterile cryotubes and frozen at $-80^{\circ} \mathrm{C}$ until DNA extraction. Additionally, the filters were folded and put into sterile polyethylene $500 \mathrm{ml}$ Whirl-Pak ${ }^{\circledR}$ bags and frozen at $-80^{\circ} \mathrm{C}$ until DNA extraction.

\section{DNA extraction}

DNA was extracted from each VC ( $\mathrm{n}=37$ ) using the QIAamp MinElute Virus Spin Kit (Qiagen), following the manufacturer's protocol. To enable comparisons among $\mathrm{VCs}$, the volume of $\mathrm{VC}$ extracted was standardized to the same initial volume of water sample using the concentration factor, which was calculated by dividing the initial sample volume by the volume of each VC. The frozen PVDF and GC50 filters were aseptically cut in squares of $\sim 1 \mathrm{~cm}^{2}$, and sliced into strips with a sterile razor blade. Filter sections were placed into Power Bead tubes (Mo-Bio). DNA was extracted from the filter sections using the Mo-Bio Ultra Clean Soil DNA extraction kit, according to the manufacturer's instructions. The volume of filter extracts was standardized to the initial volume of sample, as described above. All DNA extracts were stored at $-80^{\circ} \mathrm{C}$ until required.

\section{PCR amplification and DGGE fingerprinting}

DNA polB genes from phycodnaviruses

DNA polB gene fragments were amplified using the primers AVS1 ( $5^{\prime}-\mathrm{GA}[\mathrm{A} / \mathrm{G}]$ GGI GCI ACI GTI [C/T]TI GA[C/T] GC-3') and AVS2 (5'-GCI GC[A/G] TAI C[G/T][C/T] TT[C/T] TTI [G/C][A/T][A/G] TA-3'), which yield $\sim 700 \mathrm{bp}$ products (Chen \& Suttle 1995a,b). Following Short \& Suttle (2003), polB was amplified using 2 separate PCR assays to increase DNA yields for DGGE analysis. For the first-stage PCR, either $5 \mu \mathrm{l}$ of extracted DNA from the VCs or 2.2 to $8.3 \mu \mathrm{l}$ of extracted DNA from each PVDF filter, standardized to the same initial volume of seawater sample, served as the DNA template in the PCR mixtures, which contained $1 \mathrm{U}$ of Platinum Taq DNA polymerase, $1 \times$ Platinum Taq DNA polymerase 
assay buffer (20 mM Tris-HCl, $50 \mathrm{mM} \mathrm{KCl,} \mathrm{pH}$ 8.4), $0.2 \mathrm{mM}$ of each deoxyribonucleoside triphosphate (dNTP), $1.5 \mathrm{mM} \mathrm{MgCl}_{2}, 0.2 \mu \mathrm{M}$ of AVS1 and $0.6 \mu \mathrm{M}$ of AVS2, adjusted to a final volume of $50 \mu \mathrm{l}$ with sterile water. Negative controls contained all reagents with sterile water substituted for the DNA templates. PCR amplification was done on a PCR Express Hybaid $^{\mathrm{TM}}$ Thermal cycler (Thermo Hybaid) using 32 cycles of denaturation at $95^{\circ} \mathrm{C}$ for $90 \mathrm{~s}$, annealing at $45^{\circ} \mathrm{C}$ for $45 \mathrm{~s}$, extension at $72^{\circ} \mathrm{C}$ for $45 \mathrm{~s}$, with an initial denaturation at $95^{\circ} \mathrm{C}$ for $90 \mathrm{~s}$ and a final extension at $72^{\circ} \mathrm{C}$ for $10 \mathrm{~min}$. Three separate PCR assays were performed for each sample to minimize PCR biases that might occur in individual PCR reactions. A $12 \mu \mathrm{l}$ sample of the PCR products was checked by electrophoresis on $1.5 \%(\mathrm{w} / \mathrm{v})$ agarose gels in $0.5 \times \mathrm{TBE}$ buffer (45 mM Tris-borate, 1 mM EDTA, pH 8.0) and bands were photographed on an Alpha Imager 3400 UV transilluminator with a video image processor (Alpha Innotech) after SYBR Gold (Invitrogen) staining. Then, gel plugs of PCR products were excised with sterile glass Pasteur pipettes, eluted in $80 \mu \mathrm{l}$ of sterile water, and heated for $20 \mathrm{~min}$ at $70^{\circ} \mathrm{C}$. For the second-stage PCR, $3 \mu \mathrm{l}$ of the eluted DNA was added as the template, using the same mixture and conditions as for the first-stage PCR, except that the number of cycles was reduced to 20. PCR products were checked by electrophoresis as above.

Subsequently, polB amplicons from the secondstage PCR were separated using a Bio-Rad DCode ${ }^{\mathrm{TM}}$ Universal Mutation Detection System. Approximately $50 \mu$ of the pooled polB amplicons from 3 separate second-stage PCR assays were loaded onto $0.75 \mathrm{~mm}$ thick 6 to $7 \%(\mathrm{w} / \mathrm{v})$ polyacrylamide gels (acrylamidebisacrylamide ratio 37.5:1, Bio-Rad), featuring a linear denaturing gradient of 15 to $40 \%$ (100\% denaturant corresponded to $7 \mathrm{M}$ urea and $40 \%$ (v/v) formamide). DGGE gels were submerged in $1 \times$ TAE $(40 \mathrm{mM}$ TrisAcetate, $1 \mathrm{mM}$ EDTA, $\mathrm{pH}=8.0$ ) buffer at $60^{\circ} \mathrm{C}$ and 60 $\mathrm{V}$ was applied for $20 \mathrm{~h}$. After electrophoresis, the gels were stained with SYBR Green I (Molecular Probes; 1:10 000 dilution of stock solution) for $\sim 90 \mathrm{~min}$. DGGE banding profiles were visualized and photographed in a UV transilluminator, as described above.

Due to the large number of samples, several gels were required to carry out the DGGE analysis. Standards were produced by excising 6 to 8 evenly spaced bands, eluting them in $80 \mu \mathrm{l}$ of sterile Tris-EDTA buffer, and heating them for $20 \mathrm{~min}$ at $70^{\circ} \mathrm{C}$. Eluted DNA served as templates for a 25 cycle PCR, as above. Pooled amplicons served as standards to normalize for differences among and within gels. Standards were loaded in at least 2 to 3 lanes on each gel.

\section{MCP g23 genes of T4-like viruses}

Fragments of $g 23$ genes from T4-like viruses were amplified using the primers MZIA1-bis (5'-GAT ATT TGI GGI GTT CAG CCI ATG A-3') and MZIA-6 (5'CGC GGT TGA TTT CCA GCA TGA TTT C-3'), which yield $\sim 500 \mathrm{bp}$ products (Filée et al. 2005). A guanine-cytosine (G-C) clamp of 40 bp (5'-CGC CCG CCG CGC GCG GCG GGC GGG GCG GGG GCA CGG GGG G-3') was added to the forward primer MZIA1-bis to improve the mobility and resolution of the DGGE bands (Muyzer et al. 1993). For the PCR assays, either $3 \mu \mathrm{l}$ of extracted DNA from VCs or 1.3 to $5 \mu$ of extracted DNA from each PVDF filter, standardized to the same initial volume of seawater sample, were used as the DNA template in the PCR mixtures (final volume, $50 \mu \mathrm{l}$ ), which contained $1 \mathrm{U}$ of Platinum Taq DNA polymerase, $1 \times$ Platinum Taq DNA polymerase assay buffer, $0.2 \mathrm{mM}$ of each dNTP, $1.5 \mathrm{mM} \mathrm{MgCl}_{2}, 0.4 \mu \mathrm{M}$ of each primer and sterile water. Negative controls were run as described above. PCR conditions consisted of 35 cycles of denaturation at $95^{\circ} \mathrm{C}$ for $90 \mathrm{~s}$, annealing at $50^{\circ} \mathrm{C}$ for $1 \mathrm{~min}$ and extension at $72^{\circ} \mathrm{C}$ for $45 \mathrm{~s}$, with an initial denaturation at $95^{\circ} \mathrm{C}$ for $90 \mathrm{~s}$ and a final extension at $72^{\circ} \mathrm{C}$ for $10 \mathrm{~min}$. Positive PCR products were verified by electrophoresis in $1.5 \%$ agarose gels as outlined above.

Approximately $35 \mu \mathrm{l}$ of the pooled $g 23$ amplicons from 3 separate PCR assays were loaded onto $0.75 \mathrm{~mm}$ thick 7 to $8 \%$ polyacrylamide gels with a linear denaturing gradient of 15 to $65 \%$. DGGE analysis was performed for $20 \mathrm{~h}$ at $60 \mathrm{~V}$ and $60^{\circ} \mathrm{C}$ and selected DGGE bands were re-amplified and used as standards, as described above.

16S and 18S rDNA gene amplicons from
prokaryotes and eukaryotes

Amplification of $16 \mathrm{~S}$ rDNA was carried out using DNA extracted from the PVDF filters (e.g. 0.45 to $1.2 \mu \mathrm{m}$ size fraction) using the eubacterial specific primers 341F (5'-CCT ACG GGA GGC AGC AG-3') and 907R (5'-CCG TCA ATT C[A/C]T TTG AGT TT3'), which yield $~ 590$ bp products (Muyzer \& Ramsing 1995). Amplification of $18 \mathrm{~S}$ rDNA was carried out using DNA extracted from each PVDF and GC50 filter using the $18 \mathrm{~S}$ eukaryotic specific primers Euk1F (5'-AAC CTG GTT GAT TCC TGC CAG T-3') and Euk516R (5'-ACC AGA CTT GCC CTC C-3'), which yield $\sim 560$ bp products (Díez et al. 2001a). Both 16S and $18 \mathrm{~S}$ amplicons were generated to produce DGGE 
fingerprints of potential bacterial and eukaryotic hosts. A $40 \mathrm{bp} \mathrm{G-C} \mathrm{clamp} \mathrm{was} \mathrm{added} \mathrm{to} 341 \mathrm{~F}$ and Euk516R to improve mobility and resolution of DGGE bands (Muyzer et al. 1993, Díez et al. 2001a). Approximately 1.3 to $5 \mu$ l (standardized to the same initial volume of seawater sample) of DNA extract was used as the template in the PCR mixtures, which contained 1 U Platinum Taq, $1 \times$ Platinum Taq DNA polymerase assay buffer, $1.5 \mathrm{mM} \mathrm{MgCl}_{2}, 0.2 \mathrm{mM}$ of each dNTP, $0.3 \mu \mathrm{M}$ of each primer and $1 \mathrm{U}$ Platinum Taq DNA. PCR mixtures were adjusted to a final volume of $50 \mu \mathrm{l}$ with sterile water. Thermal cycling conditions for both $16 \mathrm{~S}$ and $18 \mathrm{~S}$ amplification consisted of initial denaturation at $95^{\circ} \mathrm{C}$ for $90 \mathrm{~s}$, followed by 10 'touchdown' cycles of denaturation at $95^{\circ} \mathrm{C}$ for $1 \mathrm{~min}$, annealing at $65^{\circ} \mathrm{C}$ (temperature decreasing by $1^{\circ} \mathrm{C}$ per cycle) for $1 \mathrm{~min}$, and extension at $72^{\circ} \mathrm{C}$ for $2 \mathrm{~min}$. This was followed by another 20 cycles at $95^{\circ} \mathrm{C}$ for $1 \mathrm{~min}, 55^{\circ} \mathrm{C}$ for $1 \mathrm{~min}$ and $72^{\circ} \mathrm{C}$ for $2 \mathrm{~min}$. The final extension step was for $10 \mathrm{~min}$ at $72^{\circ} \mathrm{C}$. The 'touchdown' PCR was performed to increase the specificity of the amplification and to reduce the formation of spurious byproducts. Subsamples of the PCR products were electrophoresed in a 1.5\% agarose gel as described above. Negative controls contained all reagents with sterile water replacing the DNA template. For each sample, PCR was performed in duplicate and then pooled prior to separation by DGGE.

Approximately $40 \mu \mathrm{l}$ of gene-specific amplicons were loaded onto $0.75 \mathrm{~mm}$ thick 7 to $8 \%$ polyacrylamide gels with a linear denaturing gradient of 20 to $60 \%$ for $16 \mathrm{~S}$ and 25 to $65 \%$ for $18 \mathrm{~S}$. DGGE was carried out for $20 \mathrm{~h}$ at $60 \mathrm{~V}$ at $60^{\circ} \mathrm{C}$, and selected DGGE bands were excised from gels, eluted and reamplified to serve as standards as described above.

\section{DGGE image analysis}

To facilitate comparison, pictures for each set of g23, polB, 16S and 18S DGGE fingerprints were analyzed separately using GelCompar II (v6.1, Applied Maths). Band positions within lanes were identified from corrected intensity plots using a minimal profiling percentage of $10 \%$ and then checked manually. After band detection, the fingerprint sets were compared through band-matching analysis in GelCompar II. Standard lanes were used to allow for comparisons within and among gels. Position tolerance for band matching was set at $0.5 \%$. Presence and absence of bands was scored as either 0 or 1 , respectively, and the resulting binary datasets were further analyzed using the multivariate software package
PRIMER v5 (PRIMER-E) following procedures described in Clarke \& Warwick (2001), as below.

\section{Statistical analysis}

Analysis of variance (ANOVA) was used to determine the statistical significance of differences in the mean number of bands from the DGGE profiles, using Systat 11 (Systat Software).

Pairwise matrices were calculated from each binary dataset (i.e. DGGE of $g 23$, polB, $16 \mathrm{~S}$ and $18 \mathrm{~S}$ ) using the Bray-Curtis dissimilarity coefficients (Bray \& Curtis 1957, Clarke 1993), as follows:

$$
S_{j k}=100\left\{1-\sum_{i=1}^{n} \frac{\left|y_{i j}-y_{i k}\right|}{\left(y_{i j}+y_{i k}\right)}\right\}
$$

where $i$ is the DGGE band compared across samples $j$ and $k$, and $y_{i j}$ and $y_{j k}$ is one set of $n$ attributes. The Bray-Curtis index gives less weight to outliers (Clarke \& Warwick 2001). Binary data were fourthroot $(\sqrt[4]{ })$-transformed prior to Bray-Curtis index calculations to give more weight to the rare DGGE bands (Clarke 1993). Different matrices were prepared to explore fingerprint variations related to season, region and depth. The resulting matrices were then ordinated through non-metric multidimensional scaling (MDS) analysis to visualize the fingerprinting results. MDS is a robust procedure that preserves the rank orders of the relative distances among data and places the data in relation to each other based on similarities among the samples (Clarke 1993). MDS plots were conducted with a standard 100 random restarts to avoid local minima, and were considered to be a good representation with Kruskal's stress values $\leq 0.2$, as calculated with PRIMER (Clarke 1993, Clarke \& Warwick 2001).

To statistically test for differences in the fingerprint patterns among seasons, stations and depths, 1-way analysis of similarity (ANOSIM) was done on each type of Bray-Curtis matrix. ANOSIM generates an overall test statistic $(R)$ that reflects the observed differences among groups compared with within groups. Typically, $R$ ranges from -1 to +1 , with $R=+1$ indicating complete discrimination among groups, and $R \leq 0$ indicating completely random grouping (Clarke \& Warwick 2001). The statistical significance of the observed $R$ was assessed by Monte-Carlo permutation tests ( $\mathrm{n}=999$ permutations).

Pairwise Bray-Curtis dissimilarity matrices were compared using the RELATE procedure in PRIMER (Clarke \& Warwick 2001). RELATE calculates a weighted Spearman's rank correlation $\left(\rho_{\mathrm{w}}\right)$ among all 
corresponding elements in each matrix, and ranges from 0 to 1 ( $\rho_{\mathrm{w}}=0$ indicates no relationship among matrices). The statistical significance of the coefficient $\rho_{\mathrm{w}}$ was assessed by Monte-Carlo permutation tests ( $\mathrm{n}=999$ permutations). Additionally, to evaluate overall interrelationships among 3 or more matrices a 'second-stage' similarity matrix was ordinated using the 2STAGE MDS analysis in PRIMER (Clarke \& Warwick 2001).

The best correlations between Bray-Curtis dissimilarity matrices and environmental variables (with Euclidean distance) were examined using BIOENV analysis (Clarke \& Warwick 2001). BIOENV selects a combination of the Euclidean distances of scaled environmental factors that may best explain variability in Bray-Curtis dissimilarity matrices, by maximizing a weighted Spearman's rank correlation coefficient $\left(\rho_{\mathrm{w}}\right)$ between every possible combination of environmental variables. The test statistic, $\rho_{\mathrm{w}}$, ranges between -1 and +1 , where $\rho_{\mathrm{w}}=+1$ indicates complete correlation between fingerprints and environmental variables, $\rho_{\mathrm{w}}=0$ indicates no correlation, and $\rho_{\mathrm{w}}=-1$ represents complete opposition. BIOENV calculates significance by Monte-Carlo permutation tests (Clarke \& Warwick 2001). All the environmental variables were standardized and log-transformed before conversion to a Euclidean distance matrix in PRIMER, and included T, S, depth, chl $a$, BA, BP and VA. All the data analyses on the DGGE profiles were performed with PRIMER.

\section{RESULTS}

\section{DNA polB amplicon fingerprints}

The AVS primers amplified $\sim 700$ bp polB gene fragments from all VC and PVDF extracts. DNA sequence analysis of 6 selected colony PCR products confirmed that the AVS primers targeted the conserved motif I of the DNA polB gene of phycodnaviruses, with top-scoring sequences similar to those retrieved from marine viral assemblages (data not shown) (Short \& Suttle 2002, 2003).

DGGE analyses revealed dynamic banding patterns, with most of the dominant bands located at almost the same position (see Fig. S1 in the Supplement at www.int-res.com/articles/suppl/a072p047_ supp.pdf). All of the samples were processed and analyzed at the same time to ensure consistency. Although pre-filtration of the samples potentially excluded some viruses or released others from cells trapped on the filters, ANOSIM pairwise comparisons of the Bray-Curtis matrix derived from the entire polB DGGE dataset (presence and absence of bands) showed an overall similarity in polB fingerprint patterns from the VCs and PVDF filters $(R=$ $0.13, \mathrm{p}>0.05)$. This was also confirmed by the MDS ordination analysis (Fig. 2), which showed no obvious separation in polB fingerprint patterns between VCs and PVDF filters. As only free viruses would be present in the VCs, these polB fingerprint patterns were analyzed in greater depth.

ANOSIM pairwise comparisons of replicate samples indicated that there were no significant differences in fingerprint patterns within and among DGGE polB fingerprints $(R=-0.03, \mathrm{p}>0.05$ and $R=0.09$, $\mathrm{p}>0.05$, respectively). This supports visual observations that DGGE generated reproducible banding patterns.

The number of DGGE bands (i.e. apparent richness) ranged from 15 to 46 bands (mean \pm SD: $27.1 \pm$ 6.7 bands). There were no significant differences found in the average number of bands among regions, seasons and depths (ANOVA, p > 0.05 in all cases).

MDS ordination and ANOSIM analyses of DGGE banding patterns (e.g. presence or absence of bands) were used to examine seasonal and spatial differences in polB fingerprint patterns (Fig. 3). The relatively low stress values (e.g. <0.20), which is a 'goodness of fit value' for the MDS ordination analysis, suggested that MDS plots gave useful 2-dimensional (2D) representations of the data (Clarke \& Warwick 2001).

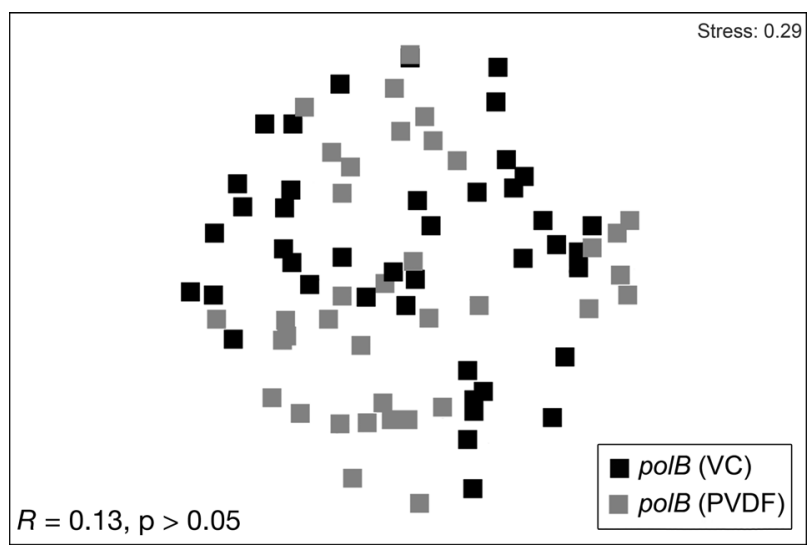

Fig. 2. Non-metric multidimensional scaling (MDS) ordination plots showing the relative similarities in the DGGE fingerprints of DNA polymerase B (polB) amplicons of viruses in the family Phycodnaviridae, obtained from viral concentrates (VC: 0.02 to $0.45 \mu \mathrm{m}$ size fraction) and polydivinylidene fluoride filters (PVDF: 0.45 to $1.2 \mu \mathrm{m}$ size fraction). Global $R$ statistics of analysis of similarities testing differences between fingerprints is also shown. MDS analyses were based on Bray-Curtis dissimilarity index of 4th roottransformed binary fingerprint data (i. e. presence and absence of DGGE bands) 
There were significant differences in $p o l B$ fingerprints among seasons $(R=0.98, \mathrm{p}<0.001)$ and regions $(R=0.36, \mathrm{p}<0.01)$, with ANOSIM showing significant differences among fall, winter, spring and summer $(0.91<R<1, \mathrm{p}<0.001$ in all cases). Among regions, ANOSIM indicated that polB fingerprints were significantly distinct in the RP relative to the MS $(R=0.43, \mathrm{p}<0.05)$ and $\mathrm{G}(R=0.72, \mathrm{p}<0.01)$. Weaker but significant changes in polB fingerprints also occurred between the MS and G regions $(R=$ $0.21, p<0.05)$. Differences in polB fingerprints were not significant with depth on spatial (depth nested with regions: $R=-0.10, \mathrm{p}>0.05$ ) or seasonal (depth nested with seasons: $\mathrm{R}=0.04, \mathrm{p}>0.05$ ) scales.

The RELATE procedure indicated a significant but weak correlation between environmental variables (T, S, depth, chl a, VA, BA and BP) and the polB fin-
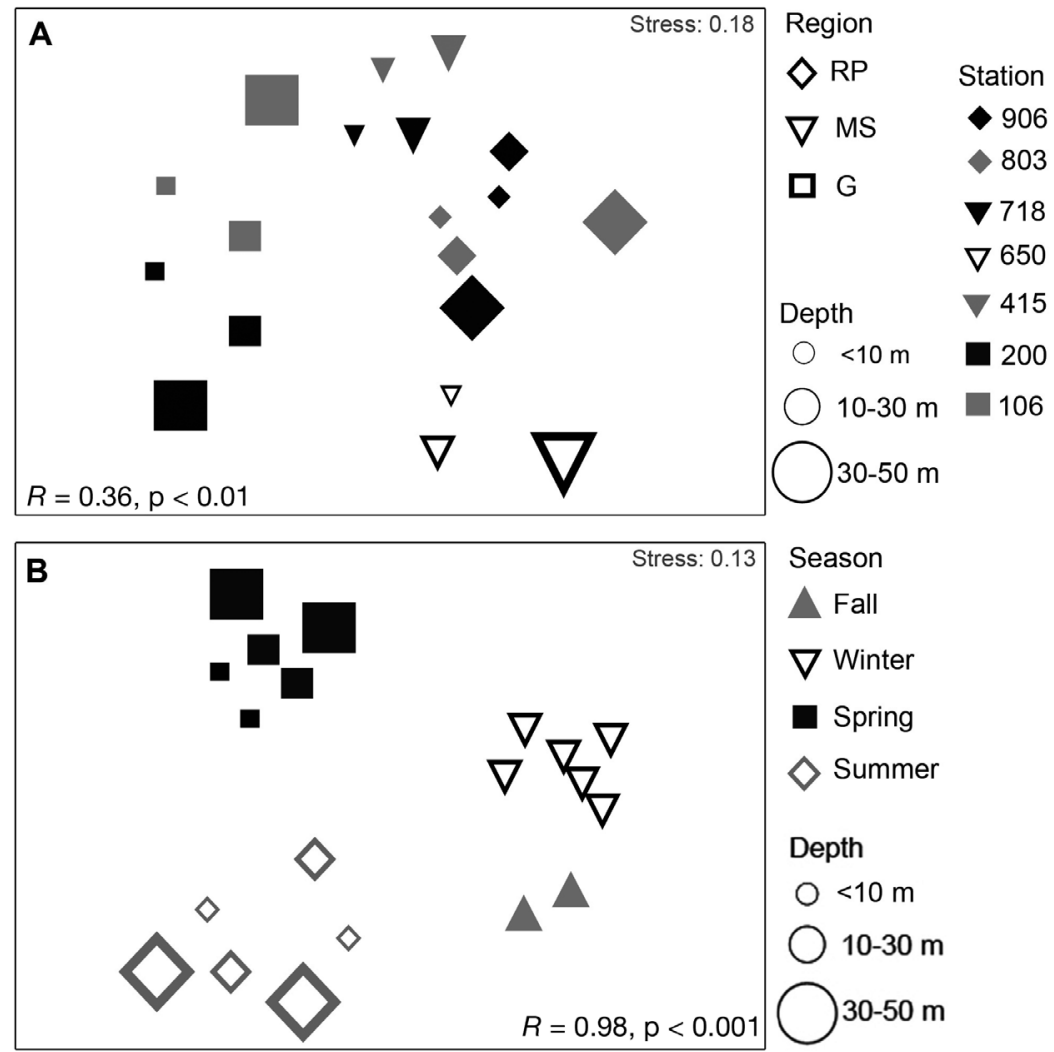

Fig. 3. Non-metric multidimensional scaling (MDS) ordination plots showing (A) spatial and (B) seasonal changes in DGGE fingerprints of DNA polymerase $\mathrm{B}($ polB) amplicons of viruses in the family Phycodnaviridae derived from viral concentrates (0.02 to $0.45 \mu \mathrm{m}$ size fraction). Testing of spatial and seasonal changes in polB fingerprints using global $R$ statistics of analysis of similarities (ANOSIM) is shown. MDS and ANOSIM analyses were based on Bray-Curtis dissimilarity indices of 4 th root-transformed binary fingerprint data (i. e. presence and absence of DGGE bands). The size of the shapes is proportional to the depths from which the samples were taken $(<10 \mathrm{~m}, 10$ to $30 \mathrm{~m}$, and 30 to $50 \mathrm{~m}$ ). Symbols show (A) stations and (B) seasons. RP: river plume; MS: midshelf; G: gulf gerprints $\left(\rho_{\mathrm{w}}=0.27, \mathrm{p}<0.01\right)$. Additional testing using BIOENV on the polB fingerprint data indicated that a combination of 3 environmental variables $(S$, BA and chl $a$ ) were best correlated $\left(\rho_{\mathrm{w}}=0.348\right)$ to the polB fingerprint patterns. Among these, BA was best correlated $\left(\rho_{\mathrm{w}}=0.295\right)$, followed by $\mathrm{S}$ and chl a $\left(\rho_{\mathrm{w}}=\right.$

The MZIA primers amplified $~ 500$ bp g23 gene fragments. Sequence analysis of 6 selected clones confirmed that MZIA primers targeted the $g 23$ gene encoding the MCP of T4-like viruses, with top-scoring sequences similar to uncultured myovirus g23 genes derived from various marine viral assemblages (data not shown) (Filée et al. 2005). Amplification from some DNA samples extracted from GC50 and PVDF filters failed, and thus these data were not included in the analysis.

Separation of $g 23$ gene amplicons by DGGE analysis revealed dynamic banding patterns (see Fig. S2 in the Supplement), with the number of bands ranging from 15 to 54 (mean \pm SD: 32.6 \pm 8.2 bands), although there were no significant differences in the average number of bands among seasons, regions and depths (ANOVA, p > 0.05, in all cases).

MDS ordination and ANOSIM were used to investigate seasonal and spatial changes in the $g 23$ fingerprints (Fig. 4). Low stress values $(<0.20)$ indicated that MDS plots were useful 2D representations of the data. There were significant changes in $g 23$ fingerprints among seasons $(R=0.76, \mathrm{p}<0.001)$ and regions $(R=0.33, \mathrm{p}<0.01)$. ANOSIM pairwise comparisons indicated that the g23 fingerprints were significantly different among the RP, MS and G regions $(0.75$ $<R<0.88, \mathrm{p}<0.01$, in all cases).

Among seasons, $g 23$ fingerprint patterns were significantly different among fall, winter, spring and summer $(0.74<$ $R<1, \mathrm{p}<0.01$, in all cases). There were no significant changes in $g 23$ fingerprints with depth on spatial $(R=$ $-0.64, \mathrm{p}>0.05)$ or seasonal scales $(R=$ $-0.31, \mathrm{p}>0.05)$. 

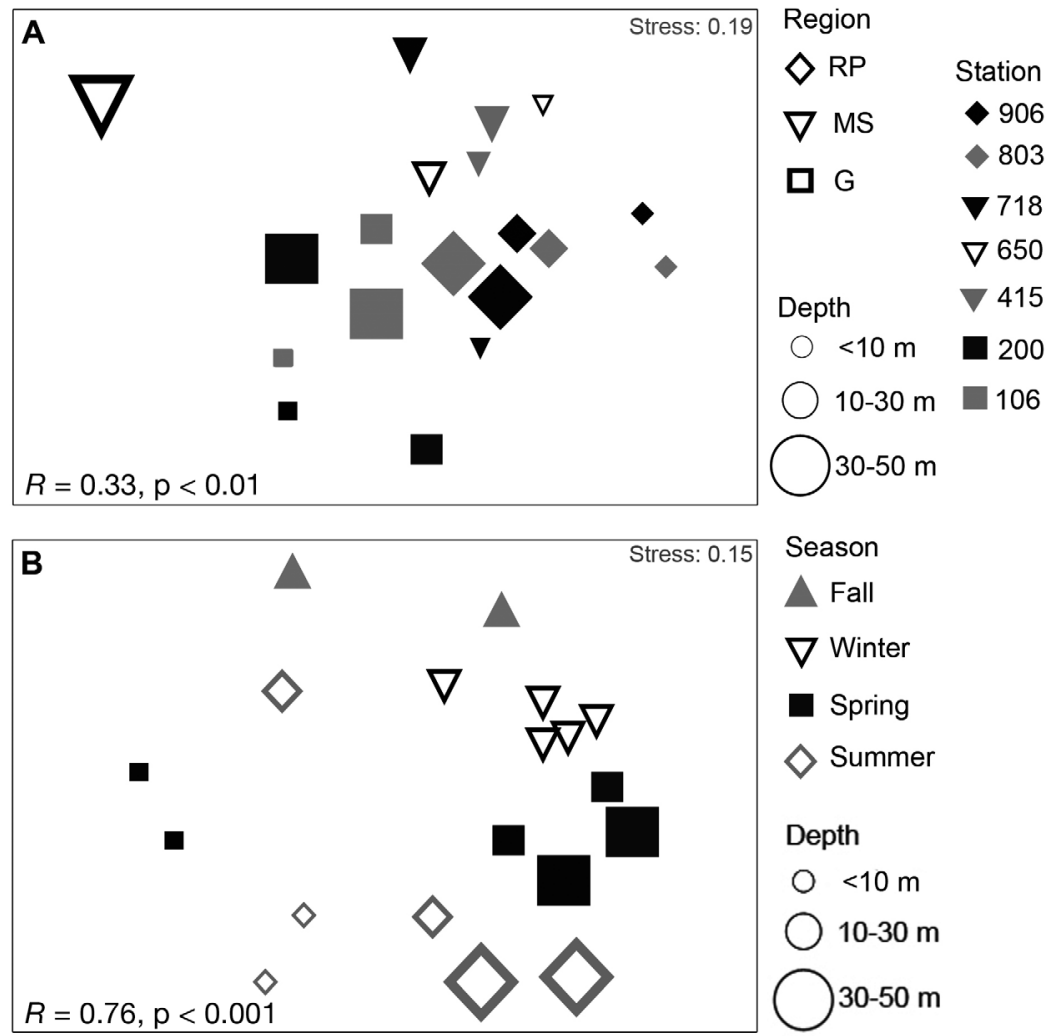

Fig. 4. Non-metric multidimensional scaling ordination plots showing (A) spatial and (B) seasonal changes in DGGE fingerprints of major capsid protein g23 amplicon of T4-like viruses in the family Myoviridae derived from viral concentrates ( 0.02 to $0.45 \mu \mathrm{m}$ size fraction). See Fig. 3 for legend details (see Figs. S3 \& S4 in the Supplement). Subsequent DNA sequences recovered from both $16 \mathrm{~S}$ and $18 \mathrm{~S}$ colony PCR products confirmed that the correct targets were amplified (data not shown).

MDS ordination and ANOSIM revealed that 16S-PVDF, 18S-PVDF and 18S-GC50 fingerprints were significantly different among seasons and regions (see Fig. 5). ANOSIM also revealed that the 18S rDNA fingerprints were significantly different between the GC50 and PVDF filters $(R=0.59, \mathrm{p}<0.01)$.

\section{Interactions between $\mathrm{g} 23, \mathrm{polB}$, $16 \mathrm{~S}$ and $18 \mathrm{~S}$ fingerprints and environmental variables}

Overall relationships between the viral fingerprints (polB-VC, polBPVDF and $g 23-\mathrm{VC})$, and those of prokaryotes (16S-PVDF), eukaryotes (18S-GC50 and 18S-PVDF) and environmental variables (e.g. T, S, depth, chl $a$, VA, BA and BP) were assessed using separate correlation analyses (e.g. RELATE subroutine in PRIMER5) (Table 1).

The RELATE procedure indicated that there were no significant relationships between environmental variables (T, S, depth, chl $a, \mathrm{VA}, \mathrm{BA}$ and $\mathrm{BP}$ ) and $g 23$ fingerprint patterns $\left(\rho_{\mathrm{w}}=0.09, \mathrm{p}>0.05\right)$. BIOENV analysis also indicated poor correlations among environmental variables and $g 23$ fingerprint patterns. Both BA and S were the best subset of variables explaining the variability of $g 23$ fingerprint patterns $\left(\rho_{\mathrm{w}}=0.124\right)$, with BA showing the highest correlation $\left(\rho_{\mathrm{w}}=0.097\right)$.

\section{S and 18S rDNA amplicon fingerprints}

The main purpose of collecting the $16 \mathrm{~S}$ and $18 \mathrm{~S}$ rDNA fingerprints was to look for relationships with the viral fingerprints; hence, the $16 \mathrm{~S}$ and $18 \mathrm{~S}$ fingerprint data were not analyzed to the same extent. Spatial and seasonal patterns in $16 \mathrm{~S}$ and 18S rDNA fingerprints were obtained through DGGE analysis of PCR-amplified DNA derived from PVDF (16S and 18S) and GC50 (18S) filters
The results indicated that both $p o l B-\mathrm{VC}$ and polBPVDF fingerprints were significantly correlated with 18S-PVDF and 18S-GC50 fingerprints, as well as with environmental variables $\left(0.19<\rho_{\mathrm{w}}<0.37, \mathrm{p}<\right.$ 0.05 , in all cases). In contrast, $g 23$ fingerprints were not significantly correlated with fingerprints of prokaryotes or eukaryotes, or environmental variables (Table 1). The overall relationships among the community structure of the microbes and viruses with the environmental variables was further investigated using a 2STAGE MDS analysis that was used to ordinate all the environmental and DGGE fingerprint data (Fig. 6).

The stress value of this representation was $0.05-\mathrm{a}$ very small value that indicates a very good fit of the 2STAGE MDS ordination. The 2STAGE MDS analysis confirmed the RELATE results (e.g. Table 1), showing a good degree of concordance among polBVC, polB-PVDF, 18S-PVDF and 18S-GC50 fingerprint patterns with the environmental variables (Fig. 6). In contrast, $g 23$ fingerprints did not group with any of the variables. 
들 융 总

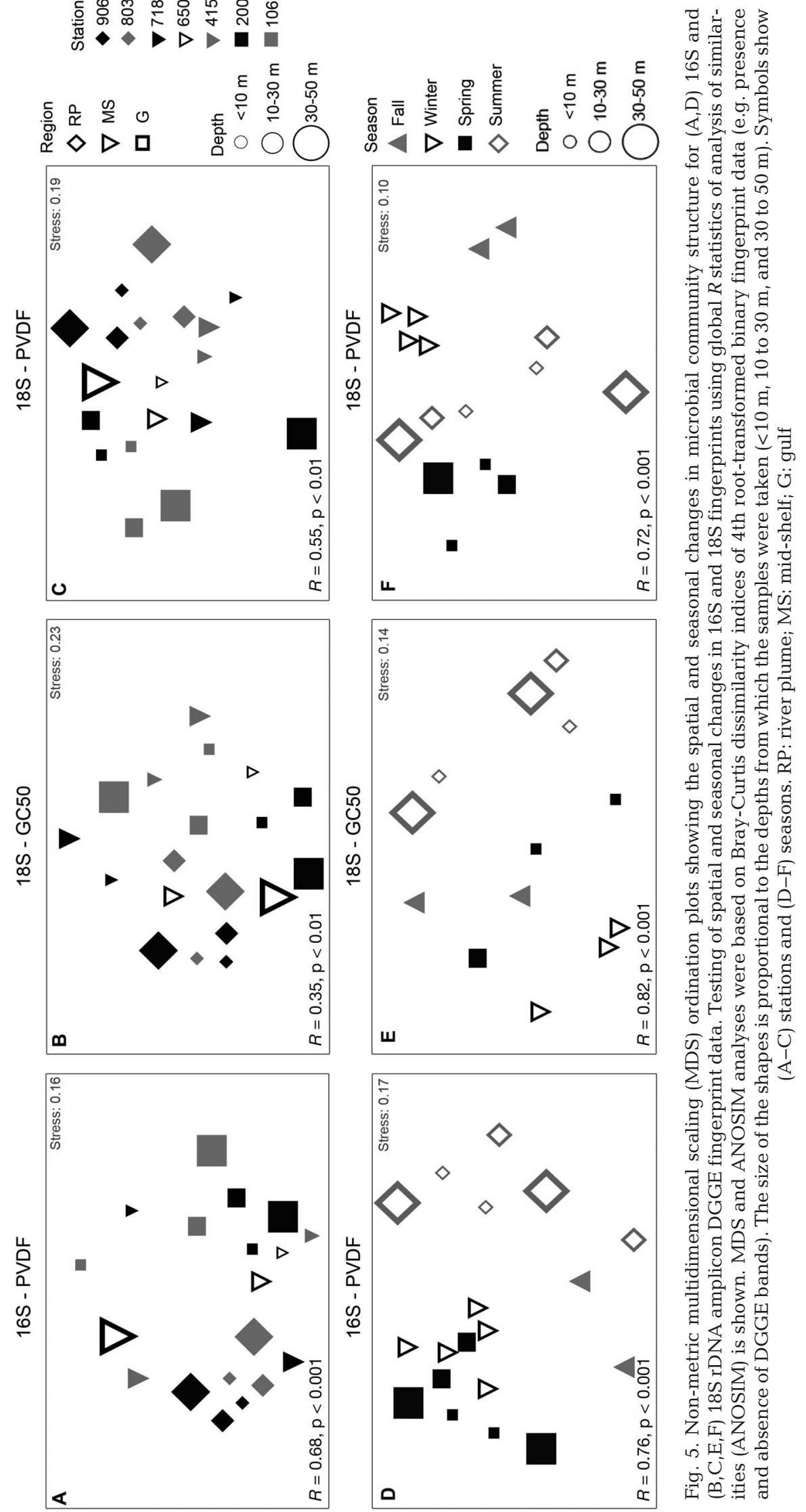


Table 1. Results of the RELATE analysis (weighted Spearman's rank correlation) testing correlations between viral fingerprint patterns (e.g. polB and g23 genes), microbial fingerprint patterns (e.g. 16S and 18S rDNA genes) and environmental variables (Env: temperature, depth, salinity, bacterial abundance, viral abundance and chlorophyll a). PVDF: polyvinylidene difluoride filter (0.45 to $1.2 \mu \mathrm{m}$ size fraction); GC50: glass fiber filter (1.2-120 $\mu \mathrm{m}$ size fraction); VC: viral concentrate $(0.02$ to $0.45 \mu \mathrm{m}$ size fraction). p-values are given in parentheses

\begin{tabular}{|lccccc|}
\hline Variable & 18S-PVDF & 18S-GC50 & 16S-PVDF & Env & polB-VC \\
\hline 18S-GC50 & 0.211 & & & & polB-PVDF \\
16S-PVDF & 0.101 & 0.118 & & & \\
Env & $0.37(0.001)$ & 0.11 & 0.152 & & \\
polB-VC & $0.209(0.001)$ & $0.297(0.001)$ & 0.134 & $0.269(0.001)$ & $0.316(0.001)$ \\
polB-PVDF & $0.192(0.03)$ & $0.355(0.001)$ & 0.122 & $0.291(0.01)$ & 0.113 \\
g23-VC & 0.072 & 0.051 & -0.045 & 0.062 & 0.096 \\
\hline
\end{tabular}

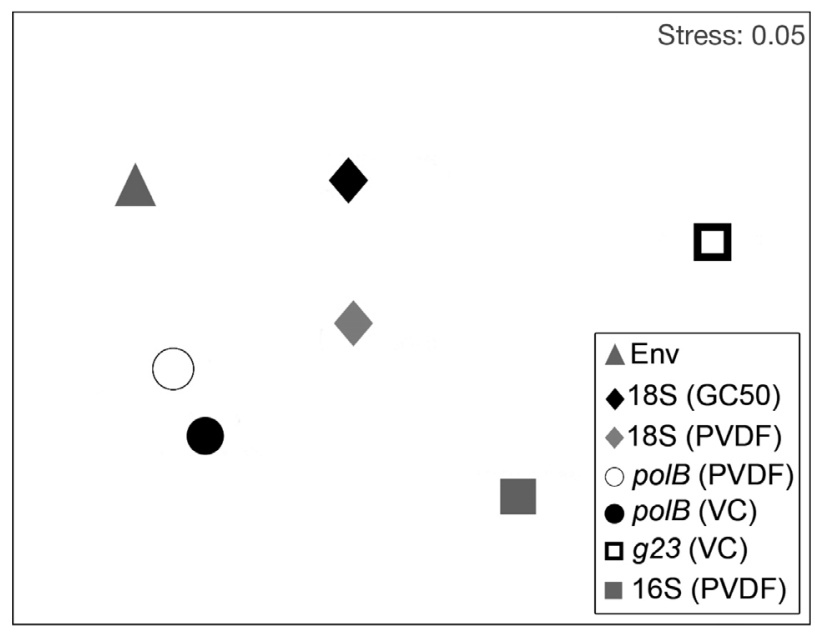

Fig. 6. Second-stage (2STAGE) non-metric multidimensional scaling ordination analysis showing relationships among viral, prokaryotic and eukaryotic fingerprint patterns (polB and $g 23,16 \mathrm{~S}$ and 18S rDNA genes, respectively) and environmental variables (Env: temperature, depth, salinity, bacterial abundance, bacterial production, viral abundance and chlorophyll a). VC: viral concentrates (0.02 to $0.45 \mu \mathrm{m}$ size fraction); PVDF: polyvinylidene fluoride filters (0.45 to $1.2 \mu \mathrm{m}$ size fraction); GC50: glass fiber filters (1.2 to $120 \mu \mathrm{m}$ size fraction)

\section{DISCUSSION}

This study examined patterns in the genetic makeup in natural assemblages of T4-like viruses and phycodnaviruses, and how it varied with changes in the prokaryotic and eukaryotic communities, and environmental conditions. The viruses in these groups infect a broad range of bacteria and microalgae, and changes in their diversity can be readily followed using well-established genetic markers.

Previous studies have shown that Arctic seas harbor diverse microbial assemblages (Angly et al. 2006, Kirchman et al. 2010, Lovejoy et al. 2011) that vary spatially and seasonally in Arctic-shelf waters (Lovejoy et al. 2006, Alonso-Sáez et al. 2008, Hamilton et al. 2008, Garneau et al. 2009, Comeau et al. 2011); however, relatively little is known about the genetic composition of the viral assemblages. Inherent genetic richness of microbial assemblages combined with highly dynamic environmental conditions make the Canadian Arctic Shelf an excellent location to unravel the relationships between microbial community structure and environmental conditions.

\section{Temporal and spatial changes in viral and cellular communities}

This study revealed distinct spatial and seasonal differences in the $g 23$ and polB fingerprints, indicating that T4-like viruses and phycodnaviruses are dynamic components of the microbial communities on the Canadian Arctic Shelf, a system exhibiting high variability in hydrological conditions modulated by sea-ice formation and melting, and river inputs, mostly from the Mackenzie River (Carmack \& Macdonald 2002, Carmack et al. 2004, Macdonald \& Yu 2006). These conditions create a highly heterogeneous environment, which would be expected to influence the genetic structure of the microbial assemblages. Such environmental heterogeneity has been shown to influence viral abundance, distribution and infection pathways across time and space in this region (Wells \& Deming 2006, Payet \& Suttle 2008, 2013, Winter et al. 2012).

Fingerprints for $g 23$ and polB displayed stronger changes among seasons than across regions (Figs. 3 \& 4). However, seasonality was more pronounced in fingerprints for polB than $g 23$. While it is not possible to identify the breath of viral diversity captured by each PCR primer set without deep sequencing, it is likely that a smaller subset of the viral assemblages 
were targeted by the polB-specific than the g23specific primers. Since primers for polB target phycodnaviruses, which infect phytoplankton (e.g. reviewed in Dunigan et al. 2006, Wilson et al. 2009, Short 2012), and phytoplankton display marked seasonal changes in this region (Garneau et al. 2008, Payet \& Suttle 2008, Brugel et al. 2009), polB fingerprints may have mirrored phytoplankton seasonality. Alternatively, because $g 23$ primers target a broader subset of the viral assemblage, including viruses that infect phototrophic and heterotrophic prokaryotes (e.g. reviewed in Ackermann 2007, Krisch \& Comeau 2008, Clokie et al. 2010), this could have obscured seasonality in the $g 23$ fingerprints.

This study used DGGE to examine fingerprint patterns in amplicons of genes encoding the MCP ( $g 23)$ of T4-like viruses and DNA polB of phycodnaviruses. Differences among the fingerprints were compared with environmental variables and DGGE fingerprint patterns for $16 \mathrm{~S}$ and 18S rDNA gene amplicons.

Changes in the polB fingerprints were related to environmental variables and the potential host community. Approximately $35 \%$ of the variability was explained by bacterial abundance, chlorophyll $a$ and salinity, indicating that the genetic structure of the phycodnaviruses was linked to changes in the productivity and hydrological conditions. Strong changes in salinity due to river inputs and releases of dense ice-brine influence stratification of the water column, which would be expected to affect microbial communities and phycodnavirus-host interactions. Short \& Suttle (2003) used a similar DGGE approach and found that hydrological conditions were also related to seasonal changes in polB fingerprints in a temperate marine system. There were also significant correlations between polB and $18 \mathrm{~S}$ fingerprints (Table 1), showing synchrony between changes in phycodnaviruses and potential eukaryotic hosts, consistent with infection. Similar dynamics in the abundances of viruses and their potential hosts have been reported for cyanobacteria and cyanophages (Waterbury \& Valois 1993, Suttle \& Chan 1994), as well as for Micromonas pusilla and the viruses that infect it (Zingone et al. 1999). However, the coupling between $18 \mathrm{~S}$ and polB fingerprints was relatively low $\left(\rho_{\mathrm{w}}<0.4\right)$, which is not surprising given that $18 \mathrm{~S}$ rDNA from non-host organisms would also be amplified, as documented in previous studies (Díez et al. 2001b, Short \& Suttle 2003, Terrado et al. 2009, Comeau et al. 2011).

In general, environmental variables (i.e. $\mathrm{T}$, $\mathrm{S}$, depth, chl $a$, VA, BA and BP) and $18 \mathrm{~S}$ fingerprints were similarly related to changes in polB fingerprints (Table 1), indicating that these variables contribute to shaping the genetic structure of phycodnaviruses. The 2STAGE MDS ordination analysis further supported the concordance among polB and 18S fingerprints as well as the environmental variables (Fig. 6).

In contrast to the polB fingerprints, there were no significant correlations between the $g 23$ fingerprints and environmental variables $\left(\rho_{w}=0.09, p>0.05\right)$. As mentioned above, it is likely that $g 23$ primers captured a broader subset of viruses with a wider spectrum of host taxa compared with polB primers. This may have obscured relationships between $g 23$ fingerprints and environmental variables. This is consistent with recent analysis of high-throughput sequencing of $g 23$ and polB amplicons from Arctic samples, which confirmed the discrepancy in the breadth of diversity of viral subsets captured by each primer set (Payet 2012). Likewise, there were no significant correlations between $g 23$ and $16 \mathrm{~S}$ or $18 \mathrm{~S}$ fingerprints $\left(\rho_{\mathrm{w}}<0.1, \mathrm{p}>0.05\right)$ (Table 1$)$. The 2STAGE MDS ordination analysis confirmed that the $g 23$ fingerprints were not closely related to changes in environmental variables or potential host communities (Fig. 6). The lack of correlation between $g 23$ fingerprints and environmental variables or $16 \mathrm{~S}$ and $18 \mathrm{~S}$ fingerprints suggests that other variables were tied to changes in the composition of T4-like viral assemblages. Alternatively, the hosts of the T4-like viruses may have been a small subset of the prokaryotic community that was not captured by DGGE fingerprinting. In addition, given that the host range of T4like viruses is very broad (Ackermann 2007, Clokie et al. 2010), linkages between the composition of T4like viruses and the prokaryotic community may be obscured. It is also possible that the $16 \mathrm{~S}$ primers also amplified plastid 16S rDNA from eukaryotic microalgae (Schäfer et al. 2001), resulting in non-bacterial amplicons in the DGGE gels, which may have obscured the relationships between the $g 23$ and $16 \mathrm{~S}$ fingerprints. Potentially, more specific PCR targets might have revealed linkages between myoviruses and the host community. For instance, many marine T4-like viruses have cyanobacterial hosts, and by using a specific gene target for cyanomyoviruses and cyanobacteria, Mühling et al. (2005) were able to use DGGE to show co-variation between the genetic structure of Synechococcus populations and T4-like viruses in the Red Sea.

Statistical models have recently revealed that viral and prokaryotic subsets, as defined by flow cytometry, are subject to different ecological forcings on the Canadian Arctic Shelf (Winter et al. 2012). Thus, it is 
also likely that some ecological factors may have had differential influences on the spatio-temporal genetic structure of subsets of T4-like viruses and prokaryotes, which could have dampened the overall compositional relationship between T4-like viruses and prokaryotes. Alternatively, higher turnover rates in viral assemblages over time relative to prokaryotes may have resulted in the observed lack of association between T4-like viruses and prokaryotes, as has been found in a recent metacommunity study (Declerck et al. 2013).

\section{Interpretation of DGGE fingerprint patterns}

DGGE allowed complex genetic patterns within the viral assemblages to be profiled and correlated with fingerprints of host communities and environmental variables. However, like other PCR-based fingerprinting techniques, DGGE is subject to methodological biases and involves a number of assumptions. DGGE is a semi-quantitative tool that provides a snapshot of the dominant genotypes. Biases introduced during DNA extraction and PCR amplification, including preferential amplification of certain DNA templates and chimera formation (Suzuki \& Giovannoni 1996, Wang \& Wang 1996, von Wintzingerode et al. 1997, Polz \& Cavanaugh 1998, Acinas et al. 2005), as well as co-migration of amplicons with different sequences (Ferris et al. 1996, Gafan \& Spratt 2005, Nikolausz et al. 2005) can influence the results. Finally, DGGE does not discriminate among sequences that are closely related and distant; hence, different bands on a gel can be variants of the same taxon or distant relatives. Despite these limitations, DGGE allows for large-scale comparisons of samples and can effectively discriminate changes in microbial community structure (Casamayor et al. 2000, Díez et al. 2001a, Bano \& Hollibaugh 2002, Crump et al. 2003).

As indicated in 'Materials and methods', PCRbiases were minimized by pooling replicate PCR products by sample prior to separation on DGGE gels. In addition, the amount of each VC or filter extracted was standardized to the same initial sample volume to reduce potential variability in PCR yields caused by different sample sizes, and to ensure that the DGGE fingerprints among samples were comparable.

The interpretation of richness from DGGE fingerprints can be compromised by different sequences migrating the same distance (Bano \& Hollibaugh 2002, Gafan \& Spratt 2005), and by some sequences not producing detectable bands; hence, the number of genotypes is not necessarily reflected in the number of bands, although samples with more genetic richness can be expected to produce more bands. Consequently, an abundance of caution is needed when inferring relationships between the genetic richness of viruses and potential host communities.

Relationships between viral and cellular community fingerprints may be obscured because some primers capture viruses that infect a much broader taxonomic range of hosts than other sets of primers. In addition, factors such as host abundance, host defense mechanisms, community turnover, resource availability and grazing activities may blur the relationships between viral and host community fingerprints. More studies with higher technical and taxonomic resolution may reveal virus-host interactions and the ecological factors influencing these interactions. Furthermore, sequence information of the DGGE bands would enable the detection of particular taxa and potentially unveil specific virus-host interactions.

This study showed that on the Canadian Arctic Shelf, the community structure of T4-like viruses and phycodnaviruses followed distinct seasonal and spatial patterns. DGGE analysis of polB amplicons showed that the genetic structure of phycodnaviruses was related to changes in productivity and hydrological conditions, as well as to changes in the composition of eukaryotic microbial communities. This suggests that the phycodnavirus assemblages were shaped by a complex interplay between the environment and host community structure. In contrast, the genetic structure of T4-like viruses could not be related to changes in environmental conditions or the composition of the prokaryotic or eukaryotic microbial communities, suggesting that T4-like viruses may be controlled by unmeasured ecological factors, or by a subset of the prokaryotic community that was not detected by DGGE. Nevertheless, the dynamic nature in the composition of the viral communities on the Canadian Arctic Shelf is consistent with continuous ongoing lysis of host cells, implicating viruses as significant agents of microbial mortality.

However, there are caveats and limitations with using DGGE fingerprint analysis to infer relationships between viral community composition and the composition of potential host communities and environmental conditions. The effect of these limitations is to decrease the power to resolve these interactions, and hence, the interpretations made in this study are conservative. 
Acknowledgements. We are grateful to A. I. Culley and A. M. Comeau for their help in field sampling, A. C. Ortmann and A. M. Chan for their logistical support and planning, the assistance of the officers, crew and scientists aboard the CCGS 'Amundsen', and C. J. Charlesworth for improving the manuscript. We thank W. F Vincent and M-É. Garneau (Université Laval) for providing chlorophyll $a$ and bacterial production data. We also thank 3 anonymous reviewers for helpful comments on the manuscript. This study was supported by the Natural Sciences and Engineering Research Council of Canada (NSERC) through a Discovery Grant, the International Polar Year MERGE program, the Canadian Arctic Shelf Exchange Study (CASES), and the Canadian Institute for Advanced Research.

\section{LITERATURE CITED}

Acinas SG, Sarma-Rupavtarm R, Klepac-Ceraj V, Polz MF (2005) PCR-induced sequence artifacts and bias: insights from comparison of two 16S rRNA clone libraries constructed from the same sample. Appl Environ Microbiol 71:8966-8969

- Ackermann HW (2007) 5500 phages examined in the electron microscope. Arch Virol 152:227-243

Alonso-Sáez L, Sanchez O, Gasol J, Balague V, Pedrós-Alió C (2008) Winter-to-summer changes in the composition and single-cell activity of near-surface Arctic prokaryotes. Environ Microbiol 10:2444-2454

Angly FE, Felts B, Breitbart M, Salamon P and others (2006) The marine viromes of four oceanic regions. PLoS Biol 4: e368

> Bano N, Hollibaugh J (2002) Phylogenetic composition of bacterioplankton assemblages from the Arctic Ocean. Appl Environ Microbiol 68:505-518

> Bench SR, Hanson TE, Williamson KE, Ghosh D, Radosovich M, Wang K, Wommack KE (2007) Metagenomic characterization of Chesapeake Bay virioplankton. Appl Environ Microbiol 73:7629-7641

Bratbak G, Egge JK, Heldal M (1993) Viral mortality of the marine alga Emiliania huxleyi (Haptophyceae) and termination of algal blooms. Mar Ecol Prog Ser 93:39-48

$>$ Bray JR, Curtis JT (1957) An ordination of the upland forest communities of Southern Wisconsin. Ecol Monogr 27: 325-349

> Breitbart M (2012) Marine viruses: truth or dare. Annu Rev Mar Sci 4:425-448

Breitbart M, Salamon P, Andresen B, Mahaffy JM and others (2002) Genomic analysis of uncultured marine viral communities. Proc Natl Acad Sci USA 99:14250-14255

> Breitbart M, Felts B, Kelley S, Mahaffy JM, Nulton J, Salamon P, Rohwer F (2004) Diversity and population structure of a near-shore marine-sediment viral community. Proc Biol Sci 271:565-574

> Brugel S, Nozais C, Poulin M, Tremblay JÉ and others (2009) Phytoplankton biomass and production in the southeastern Beaufort Sea in autumn 2002 and 2003. Mar Ecol Prog Ser 377:63-77

Brussaard CPD, Short SM, Frederickson CF, Suttle CA (2004) Isolation and phylogenetic analysis of novel viruses infecting the phytoplankton Phaeocystis globosa (Prymnesiophyceae). Appl Environ Microbiol 70:3700-3705

Carmack EC, Macdonald RW (2002) Oceanography of the Canadian Shelf of the Beaufort Sea: a setting for marine life. Arctic 55:29-45
Carmack EC, Macdonald RW, Jasper S (2004) Phytoplankton productivity on the Canadian Shelf of the Beaufort Sea. Mar Ecol Prog Ser 277:37-50

- Casamayor EO, Schäfer H, Baneras L, Pedrós-Alió C, Muyzer G (2000) Identification of spatio-temporal differences between microbial assemblages from two neighboring sulfurous lakes: comparison by microscopy and denaturing gradient gel electrophoresis. Appl Environ Microbiol 66:499-508

> Chen F, Suttle CA (1995a) Amplification of DNA polymerase gene fragments from viruses infecting microalgae. Appl Environ Microbiol 61:1274-1278

> Chen F, Suttle CA (1995b) Nested PCR with three highly degenerate primers for amplification and identification of DNA from related organisms. Biotechniques 18:609-612

Chénard C, Suttle CA (2008) Phylogenetic diversity of cyanophage photosynthetic genes ( $p s b A)$ in marine and fresh waters. Appl Environ Microbiol 74:5317-5324

Clarke KR (1993) Non-parametric multivariate analyses of changes in community structure. Aust J Ecol 18:117-143

Clarke KR, Warwick RM (2001) Change in marine communities: an approach to statistical analysis and interpretation, 2nd edn. PRIMER-E, Plymouth

Clasen JL, Suttle CA (2009) Identification of freshwater Phycodnaviridae and their potential phytoplankton hosts, using DNA pol sequence fragments and a geneticdistance analysis. Appl Environ Microbiol 75:991-997

> Clokie MRJ, Millard AD, Mann NH (2010) T4 genes in the marine ecosystem: studies of the T4-like cyanophages and their role in marine ecology. Virol J 7:291

Comeau AM, Krisch HM (2008) The capsid of the T4 phage superfamily: the evolution, diversity, and structure of some of the most prevalent proteins in the biosphere. Mol Biol Evol 25:1321-1332

> Comeau AM, Li WKW, Tremblay JÉ, Carmack EC, Lovejoy C (2011) Arctic Ocean microbial community structure before and after the 2007 record sea ice minimum. PLoS ONE 6:e27492

Crump BC, Kling GW, Bahar M, Hobbie JE (2003) Bacterioplankton community shifts in an Arctic lake correlate with seasonal changes in organic matter source. Appl Environ Microbiol 69:2253-2268

Culley AI, Brenda FA, Steward GF (2009) Detection of inteins among diverse DNA polymerase genes of uncultivated members of the Phycodnaviridae. ISME J 3:409-418

> Declerck SA, Winter C, Shurin JB, Suttle CA, Matthews B (2013) Effects of patch connectivity and heterogeneity on metacommunity structure of planktonic bacteria and viruses. ISME J 7:533-542

> DeLong EF, Preston C, Mincer T, Rich V and others (2006) Community genomics among stratified microbial assemblages in the ocean's interior. Science 311:496-503

> Díez B, Pedrós-Alió C, Marsh TL, Massana R (2001a) Application of denaturing gradient gel electrophoresis (DGGE) to study the diversity of marine picoeukaryotic assemblages and comparison of DGGE with other molecular techniques. Appl Environ Microbiol 67:2942-2951

> Díez B, Pedrós-Alió C, Massana R (2001b) Study of genetic diversity of eukaryotic picoplankton in different oceanic regions by small-subunit rRNA gene cloning and sequencing. Appl Environ Microbiol 67:2932-2941

$>$ Dorigo U, Jacquet S, Humbert JF (2004) Cyanophage diversity, inferred from $g 20$ gene analyses, in the largest natural lake in France, Lake Bourget. Appl Environ Microbiol 70:1017-1022 
Dunigan DD, Fitzgerald LA, Van Etten JL (2006) Phycodnaviruses: a peek at genetic diversity. Virus Res 117: 119-132

Ferris MJ, Muyzer G, Ward DM (1996) Denaturing gradient gel electrophoresis profiles of $16 \mathrm{~S}$ rRNA-defined population inhabiting a hot spring microbial mat community. Appl Environ Microbiol 62:340-346

- Filée J, Tétart F, Suttle CA, Krisch HM (2005) Marine T4type bacteriophages, a ubiquitous component of the dark matter of the biosphere. Proc Natl Acad Sci USA 102: 12471-12476

Frederickson CM, Short SM, Suttle CA (2003) The physical environment affects cyanophage communities in British Columbia inlets. Microb Ecol 46:348-357

> Fuhrman JA (1999) Marine viruses and their biogeochemical and ecological effects. Nature 399:541-548

Fujii T, Nakayama N, Nishida M, Sekiya H, Kato N, Asakawa S, Kimura M (2008) Novel capsid genes (g23) of T4-type bacteriophages in a Japanese paddy field. Soil Biol Biochem 40:1049-1058

Fuller NJ, Wilson WH, Joint IR, Mann NH (1998) Occurrence of a sequence in marine cyanophages similar to that of T4 g20 and its application to PCR-based detection and quantification techniques. Appl Environ Microbiol 64:2051-2060

Gafan GP, Spratt DA (2005) Denaturing gradient gel electrophoresis gel expansion (DGGEGE) - an attempt to resolve the limitations of co-migration in the DGGE of complex polymicrobial communities. FEMS Microbiol Lett 253:303-307

Garneau MÉ, Roy S, Lovejoy C, Gratton Y, Vincent WF (2008) Seasonal dynamics of bacterial biomass and production in a coastal Arctic ecoystem: Franklin Bay, western Canadian Arctic. J Geophys Res 113, C07S91, doi: 10.1029/2007JC004281

> Garneau MÈ, Vincent WF, Terrado R, Lovejoy C (2009) Importance of particle-associated bacterial heterotrophy in a coastal Arctic ecosystem. J Mar Syst 75:185-197

Gimenes MV, Zanotto PMA, Suttle CA, da Cunha HB, Mehnert DU (2012) Phylodynamics and movement of Phycodnaviruses among aquatic environments. ISME J 6:237-247

> Hamilton AK, Lovejoy C, Galand PE, Ingram RG (2008) Water masses and biogeography of picoeukaryote assemblages in a cold hydrologically complex system. Limnol Oceanogr 53:922-955

Kirchman DL, Cottrell MT, Lovejoy C (2010) The structure of bacterial communities in the western Arctic Ocean as revealed by pyrosequencing of 16S rRNA genes. Environ Microbiol 12:1132-1143

> Krisch HM, Comeau AM (2008) The immense journey of bacteriophage T4 - from d'Hérelle to Delbruck and then to Darwin and beyond. Res Microbiol 159:314-324

> Larsen JB, Larsen A, Bratbak G, Sandaa RA (2008) Phylogenetic analysis of members of the Phycodnaviridae virus family, using amplified fragments of the major capsid protein gene. Appl Environ Microbiol 74:3048-3057

> Lindell D, Sullivan MB, Johnson ZI, Tolonen AC, Rohwer F, Chisholm SW (2004) Transfer of photosynthesis genes to and from Prochlorococcus viruses. Proc Natl Acad Sci USA 101:11013-11018

López-Bueno A, Tamames J, Velázquez D, Moya A, Quesada A, Alcami A (2009) High diversity of the viral community from an Antarctic lake. Science 326:858-861

Lovejoy C, Massana R, Pedrós-Alió C (2006) Diversity and distribution of marine microbial eukaryotes in the Arctic Ocean and adjacent seas. Appl Environ Microbiol 72: 3085-3095

Lovejoy C, Galand PE, Kirchman DL (2011) Picoplankton diveristy in the Arctic Ocean and surrounding seas. Mar Biodiversity 41:5-12

Macdonald RW, Yu Y (2006) The Mackenzie Estuary of the Arctic Ocean. In: Wangersky P (ed) The handbook of environmental chemistry: estuaries. Springer, Berlin

> Mann NH, Cook A, Millard A, Bailey S, Clokie MRJ (2003) Marine ecosystems: bacterial photosynthesis genes in a virus. Nature 424:741

Marston MF, Amrich CG (2009) Recombination and microdiversity in coastal marine cyanophages. Environ Microbiol 11:2893-2903

Millard A, Clokie MRJ, Shub DA, Mann NH (2004) Genetic organization of the psbAD region in phages infecting marine Synechococcus strains. Proc Natl Acad Sci USA 101:11007-11012

> Mühling M, Fuller NJ, Millard A, Somerfield PJ and others (2005) Genetic diversity of marine Synechococcus and co-occuring cyanophage communities: evidence for viral control of phytoplankton. Environ Microbiol 7:499-508

Muyzer G, Ramsing NB (1995) Molecular methods to study the organization of microbial communities. Water Sci Technol 32:1-9

> Muyzer G, De Waal E, Uitterlinden A (1993) Profiling of complex microbial populations by denaturing gradient gel electrophoresis analysis of polymerase chain reaction-amplified genes coding for 16S rRNA. Appl Environ Microbiol 59:695-700

Nagasaki K, Bratbak G (2010) Isolation of viruses infecting photosynthetic and nonphotosynthetic protists. In: Wilhelm SW, Weinbauer MG, Suttle CA (eds) Manual of aquatic viral ecology. ASLO, Waco, TX

Nagasaki K, Ando M, Itakura S, Imai I, Ishida Y (1994) Viral mortality in the final stage of Heterosigma akashiwo (Raphidophyceae) red tide. J Plankton Res 16:1595-1599

Nikolausz M, Sipos R, Rêvész S, Székely A, Marialigeti K (2005) Observation of bias associated with re-amplification of DNA isolated from denaturing gradient gels. FEMS Microbiol Lett 244:385-390

Payet JP (2012) Ecology and diversity of marine viruses on the Canadian Arctic Shelf, Arctic Ocean. PhD dissertation, University of British Columbia, Vancouver

> Payet JP, Suttle CA (2008) Physical and biological correlates of virus dynamics in the southern Beaufort Sea and Amundsen Gulf. J Mar Syst 74:933-945

Payet JP, Suttle CA (2013) To kill or not to kill: the balance between lytic and lysogenic viral infection is driven by trophic status. Limnol Oceanogr 58:465-474

Polz MF, Cavanaugh CM (1998) Bias in template-to-product ratios in multi-template PCR. Appl Environ Microbiol 64: 3724-3730

> Rowe JM, Fabre MF, Gobena D, Wilson WH, Wilhelm SW (2011) Application of the major capsid protein as a marker of the phylogenetic diversity of Emiliania huxleyi viruses. FEMS Microbiol Ecol 76:373-380

Sandaa RA, Larsen A (2006) Seasonal variations in virushost populations in Norwegian coastal waters: focusing on the cyanophage community infecting marine Synechococcus spp. Appl Environ Microbiol 72:4610-4618

Sandaa RA, Short SM, Schroeder DC (2010) Fingerprinting aquatic virus communities. In: Wilhelm SW, Weinbauer MG, Suttle CA (eds) Manual of aquatic viral ecology. 
ASLO, Waco, TX

Schäfer H, Bernard L, Courties C, Lebaron P and others (2001) Microbial community dynamics in Mediterranean nutrient-enriched seawater mesocosms: changes in the genetic diversity of bacterial populations. FEMS Microbiol Ecol 34:243-253

Schroeder DC, Oke J, Hall M, Malin G, Wilson WH (2003) Virus succession observed during an Emiliania huxleyi bloom. Appl Environ Microbiol 69:2484-2490

Short SM (2012) The ecology of viruses that infect eukaryotic algae. Environ Microbiol 14:2253-2271

Short SM, Suttle CA (1999) Use of polymerase chain reaction and denaturing gradient gel electrophoresis to study diversity in natural virus communities. Hydrobiologia 401:19-32

Short SM, Suttle CA (2002) Sequence analysis of marine virus communities reveals that groups of related algal viruses are widely distributed in nature. Appl Environ Microbiol 68:1290-1296

Short SM, Suttle CA (2003) Temporal dynamics of natural communities of marine algal viruses and eukaryotes. Aquat Microb Ecol 32:107-119

Short CM, Suttle CA (2005) Nearly identical bacteriophage structural gene sequences are widely distributed in both marine and freshwater environments. Appl Environ Microbiol 71:480-486

Short SM, Chen F, Wilhelm SW (2010) The construction and analysis of marker gene libraries. In: Wilhelm SW, Weinbauer MG, Suttle CA (eds) Manual of aquatic viral ecology. ASLO, Waco, TX

Sullivan MB, Coleman ML, Quinlivan V, Rosenkrantz JE and others (2008) Portal protein diversity and phage ecology. Environ Microbiol 10:2810-2823

Suttle CA (2005) Viruses in the sea. Nature 437:356-361

Suttle CA (2007) Marine viruses - major players in the global ecosystem. Nat Rev Microbiol 5:801-812

Suttle CA, Chan AM (1994) Dynamics and distribution of cyanophages and their effect on marine Synechococcus spp. Appl Environ Microbiol 60:3167-3174

Suttle CA, Chan AM, Cottrell MT (1991) Use ultrafiltration to isolate viruses from seawater which are pathogens of marine phytoplankton. Appl Environ Microbiol 57: 721-726

Suzuki MT, Giovannoni SJ (1996) Bias caused by template annealing in the amplification of mixtures of 16S rRNA genes by PCR. Appl Environ Microbiol 62:625-630

Terrado R, Vincent WF, Lovejoy C (2009) Mesopelagic protists: diversity and succesion in a coastal Arctic ecosystem. Aquat Microb Ecol 56:25-40

Van Etten JL, Lane LC, Dunigan DD (2010) DNA viruses: the really big ones (Giruses). Annu Rev Microbiol 64:83-99

Editorial responsibility: Gunnar Bratbak,

Bergen, Norway von Wintzingerode F, Göbel UB, Stackebrandt E (1997) Determination of microbial diversity in environmental samples: pitfalls of PCR-based rRNA analysis. FEMS Microbiol Rev 21:213-229

- Wang GCY, Wang Y (1996) The frequency of chimeric molecules as a consequence of PCR coamplification of $16 \mathrm{~S}$ rRNA genes from different bacterial species. Microbiology 142:1107-1114

> Waterbury JB, Valois FW (1993) Resistance to co-occurring phages enables marine Synechococcus communities to coexist with cyanophages abundant in seawater. Appl Environ Microbiol 59:3393-3399

> Weinbauer MG (2004) Ecology of prokaryotic viruses. FEMS Microbiol Rev 28:127-181

> Wells LE, Deming JW (2006) Significance of bacteriovory and viral lysis in bottom waters of Franklin Bay, Canadian Arctic, during winter. Aquat Microb Ecol 43: 209-221

> Wilhelm SW, Carberry MJ, Eldridge ML, Poorvin L, Saxton MA, Doblin MA (2006) Marine and freshwater cyanophages in a Laurentian Great Lake: evidence from infectivity assays and molecular analyses of g20 genes. Appl Environ Microbiol 72:4957-4963

Williamson SJ, Rusch DB, Yooseph S, Halpern AL and others (2008) The Sorcerer II global ocean sampling expedition: metagenomic characterization of viruses within aquatic microbial samples. PLoS ONE 3:e1456

Wilson WH, Fuller NJ, Joint IR, Mann NH (1999) Analysis of cyanophage diversity in the marine environment using denaturing gradient gel electrophoresis. In: Bell CR, Brylinsky M, Johnson-Green P (eds) Microbial biosystems - new frontiers: Proc 8th Int Symp Microbial Ecology. Atlantic Canada Society for Microbial Ecology, Halifax, p 565-571

Wilson WH, Van Etten JL, Allen MJ (2009) The Phycodnaviridae: the story of how tiny giants rule the world. Curr Top Microbiol Immunol 328:1-42

> Winter C, Payet JP, Suttle CA (2012) Modeling the winterto-summer transition of prokaryotic and viral abundance in the Arctic Ocean. PLoS ONE 7:e52794

- Wommack KE, Colwell RR (2000) Virioplankton: viruses in aquatic ecosystems. Microbiol Mol Biol Rev 64:69-114

> Zhong Y, Chen F, Wilhelm SW, Poorvin L, Hodson RE (2002) Phylogenetic diversity of marine cyanophage isolates and natural virus communities as revealed by sequences of viral capsid assembly protein gene g20. Appl Environ Microbiol 68:1576-1584

- Zingone A, Sarno D, Forlani G (1999) Seasonal dynamics in the abundance of Micromonas pusilla (Prasinophyceae) and its viruses in the Gulf of Naples (Mediterranean Sea). J Plankton Res 21:2143-2159

Submitted: October 24, 2013; Accepted: January 21, 2014

Proofs received from author(s): February 24, 2014 